\title{
Investigation of Direct Electrochemical Oxidation of Neonicotinoid Pesticide Thiamethoxam in Water
}

\author{
Stevan Lj. Stupar ${ }^{1)}$ \\ Negovan D. Ivanković ${ }^{2)}$ \\ Branimir N. Grgur ${ }^{1)}$ \\ Anđelka V. Tomašević ${ }^{3)}$ \\ Dušan Ž. Mijin ${ }^{1)}$ \\ Kosana Koprivica $^{2)}$
}

\begin{abstract}
In recent decades an increase usage of chemicals in many ways of modern life is evident. So, the possibility of its intake into organisms, human and animals poisoning and health damage, is nowadays on a high level, especially when it comes to disaster situations caused by using toxic chemicals in terrorist attacks or for military purposes. If we look ahead, the risk of pesticide contamination of the water and soil, as one of the most important resources for surviving, is always present. The wide spectra of pesticide negative effects on the environment initiate the increasing number of investigations of efficient pesticide removal methods, especially from water. The aim of this study was to investigate the efficiency of direct electrochemical oxidation as a method for in-situ degradation of pesticides in the aquatic environment, depending on the concentration of pesticides, present electrolytes, applied current and the $\mathrm{pH}$ value of the medium. As a model molecule, the neonicotinoid pesticide thiamethoxam was used. Kinetics of thiamethoxam degradation in aqueous solution was followed by UV/Vis spectrometry.
\end{abstract}

Key words: electrochemical oxidation, pesticides, kinetics parameters, IrOX anode, energy consumption, UV/Vis spectroscopy.

\section{Introduction}

$\mathrm{T}$ HE The modern way of life is in many ways connected with the increasing use of different chemical substances, which, depending on the circumstances, can be used in a positive context (for the needs of hygienic household maintenance, in agriculture with the aim of increasing the yield per unit area of arable land, etc.) or in a negative context: if applied for military purposes $[1,2]$ or for terrorist attacks [3, 4]. By applying the mentioned toxic chemical substances, a person is, literally, forced to live with poisons, aware of being faced with the current risk posed by acute poisonings with the possibility of chronic consequences. Some previous researches prove that organism exposure to pesticides and their natural residuals intake of pesticides into organism may have carcinogenic and mutagenic effects, also their toxicity includes increased oxidative stress, leading to cellular damage and the generation of toxic metabolites [5-8].

More attention has been aroused in recent years on the presence of pesticides, antibiotics and toxic metals in amounts higher than the ecosystem can receive without major consequences, especially in the wastewater originated from agriculture processes (e.g. involving crop farming, aquaculture, agricultural product processing industry) [9]. The presence of pesticides in water systems initiates the increasing of quality parameters values of water as total organic carbon (TOC) [10], chemical oxygen demands (COD) [11, 12], biological oxygen demand (BOD) [13], total dissolved solids [5]. High values of these parameters have negative effects on conventional wastewater treatment, inhibiting the biological step of wastewater treatment [14]. The wide spectra of pesticide negative effects on the ecosystem initiate the increasing number of investigations of efficient pesticide removal methods from water and soil. A very important fact is that pesticides can be converted into the less toxic compounds by decomposition processes, although there is a possibility that the newly formed decomposition products will be extremely toxic [15]. According to previous researches, the promising processes for pesticide removal are adsorption [16, 17], electrochemical oxidation [18], and Advanced Oxidation Processes (AOPs) [19].

Depending on the mechanism of the oxidizing agent generation, electrochemical oxidation can be divided into direct and indirect electrochemical oxidation. In an indirect oxidation process, strong oxidants (mainly "active chlorine" species or hydroxyl radicals) are first produced in the bulk of solution via electrochemical reactions, and then these oxidants react with pollutants. The direct electrochemical oxidation using "active" anodes is based on direct electron exchange between organic compounds and an active surface of an anode. As a product of redox reactions onto the anode the intermediaries (e.g. "active oxygen" and hydroxyl radicals) are formed for further oxidation of organic compounds. In the first step of the direct electrochemical oxidation process (Eq.1), water molecules have been adsorbed onto the $\mathrm{IrO}_{\mathrm{X}}$ surface $(M)$ in hydroxyl radical form [20, 21]:

\footnotetext{
1) Faculty of Technology and Metallurgy, University of Belgrade, Karnegijeva 4, 11020 Belgrade, SERBIA

2) University of Defense, Military Academy, Pavla Jurišića Sturma 33, 11000 Belgrade, SERBIA

3) Institute of Pesticides and Environmental Protection, Banatska 31b, P.O. Box 163, 11080 Belgrade-Zemun, SERBIA

Correspondence to: Stevan Stupar, e-mail: stevan.stupar13@gmail.com
} 


$$
\mathrm{M}+\mathrm{H}_{2} \mathrm{O} \rightarrow \mathrm{M}\left({ }^{\bullet} \mathrm{OH}\right)_{\text {ads }}+\mathrm{H}^{+}+\mathrm{e}^{-}
$$

Because of the "active" anode characteristic to highly interact with hydroxyl radicals, after desorption from $\mathrm{IrO}_{\mathrm{X}}$ surface higher oxides (MO) can be generated. Generation of higher oxides is presented by Eq.2:

$$
\mathrm{M}\left({ }^{\bullet} \mathrm{OH}\right)_{\mathrm{ads}} \rightarrow \mathrm{MO}+\mathrm{H}^{+}+\mathrm{e}^{-}
$$

Further degradation of the higher oxides gives the molecular oxygen to the reactor (Eq.3):

$$
2 \mathrm{MO} \rightarrow 2 \mathrm{M}+\mathrm{O}_{2}
$$

The negative effects of organophosphates and carbamates presence in the environmental initiate the development of neonicotinoid pesticides for plant protection [22]. Neonicotinoid pesticides are highly selective and efficiently activate the nicotinic receptors in the central nervous system of insects. The important characteristics of pesticides from the neonicotinoids group are low toxicity onto mammalian organisms during acute inhalation exposure, which makes these pesticides very acceptable for pest control [23]. The presence of neonicotinoids in food, aquatics, air, and indoor dust can be dangerous in multiple ways on mammals and humans, such as toxic effects on the nerve system, immune system and negative effects on kidneys and reproductive system [24]. The mentioned characteristics and easy availability of neonicotinoid pesticides posed a threat to the security of society due to their possible use for terrorist purposes. Besides the imidacloprid and acetamiprid, thiamethoxam (TMX) (Fig.1) is one of the three most important neonicotinoid pesticides for pest control.

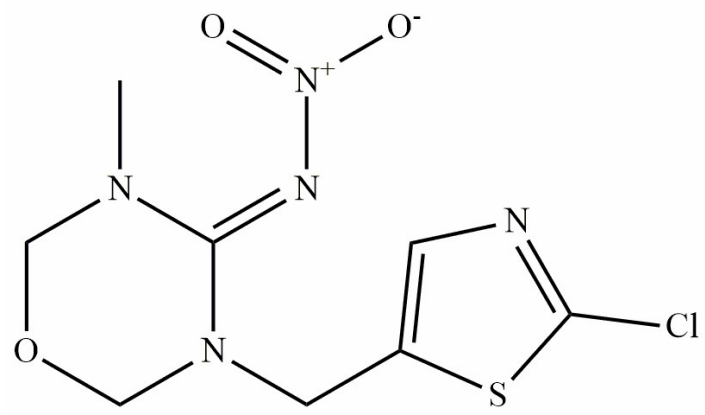

Figure 1. Molecular structure of neonicotinoid pesticide thiamethoxam

During the emergency situations caused by terrorist acts, or during the war, the water is one of the most important resources for surviving. The aim of this study was to investigate the efficiency of direct electrochemical oxidation as a method for in-situ degradation of pesticides in the aquatic environment, depending on the concentration of pesticides, electrolytes present, current strength and the $\mathrm{pH}$ value of the medium and the energy consumption during the process as an important parameter to obtain the viability of the process during war and terroristic actions. As a pesticide model molecule, the neonicotinoid pesticide thiamethoxam was used.

The electrochemical oxidation of thiamethoxam was only investigated by the Lebik-Elhadi et al. [11] using the "nonactive" boron-doped-diamond anode. To our knowledge, direct electrochemical oxidation using $\mathrm{IrO}_{\mathrm{x}}$ anode was not performed yet. The change of thiamethoxam concentration in aqueous solution was followed via UV/Vis spectrometry.

\section{Experimental Part}

\section{Reagent \& Materials}

The neonicotinoid insecticide thiamethoxam was obtained from Shenzhen Yufull Industry Co. Ltd., Shenzhen, China. $\mathrm{Na}_{2} \mathrm{SO}_{4}$ was used as an electrolyte, purchased from Centrohem, Serbia. For $\mathrm{pH}$ value adjustment, $\mathrm{H}_{2} \mathrm{SO}_{4}$ and $\mathrm{NaOH}$ were used (Sigma-Aldrich, USA). The used chemicals were of analytical grade or higher. The deionized water used throughout the whole experiment was obtained using Millipore Waters Milli-Q (USA) purification system. The PAR M273 (Iskra, Slovenia) potentiostat/galvanostat in galvanostatic mode was used as a source of the current. $5 \mathrm{~cm}^{2}$ plate of IrOx (De Nora, Italy) was used as anode material, while $10 \mathrm{~cm}^{2}$ plate made from austenite $18 \mathrm{Cr} / 8 \mathrm{Ni}$ stainless steel series 304 was used as a cathode.

The pesticide degradation was followed by UV/Vis Shimadzu 1800 spectrophotometer (Japan). The $\mathrm{pH}$ value adjustment was controlled using Hanna pH Meter HI-2210 (Italy). The evenly mixing during electrochemical oxidation was obtained by the magnetic stirrer produced by Heidolph (Germany).

\section{Electrochemical oxidation}

The direct electrochemical oxidation was performed in undivided, open reactors at room temperature with $200 \mathrm{ml}$ of electrolyte capacity with constant mixing speed of $750 \mathrm{rpm}$. The electrolytes used were consisted of dissolved $\mathrm{Na}_{2} \mathrm{SO}_{4}$ $(0.15-0.30 \mathrm{M})$ and thiamethoxam water solution $(0.125-0.5$ $\left.\mathrm{x} 10^{-4} \mathrm{M}\right)$. The electrodes were immersed in an electrolyte solution with a $3 \mathrm{~mm}$ of the distance between anode and cathode. The continuous homogenization of the solution was obtained by mixing on a magnetic stirrer.

Kinetics of insecticide degradation was followed by UV$\mathrm{Vis}$ spectroscopy. The $\mathrm{pH}$ value at the beginning of pesticide degradation was performed by the addition of $0.1 \mathrm{M} \mathrm{H}_{2} \mathrm{SO}_{4}$ for acidification or the same concentration of $\mathrm{NaOH}$ solution for an alkaline solution. During experiments, at least three measurements were done for each determination of all evaluated parameters.

\section{Pesticide removal analysis and energy consumption}

Pesticide degradation was monitored by absorbance measurement using UV-Vis spectrometry. The efficiency of thiamethoxam removal using $\mathrm{IrO}_{\mathrm{x}}$ anode was calculated using Eq.4:

$$
\text { Removalefficiency }(\%)=\frac{\left(C_{0}-C_{t}\right)}{C_{0}} \cdot 100
$$

where $C_{0}$ and $C_{t}$ represents the initial pesticide concentration and pesticide concentration at a specific time of the degradation process.

To design a wastewater treatment plant, the kinetics parameters obtained by modeling experimental data is a necessary parameter. The kinetics of thiamethoxam degradation by the direct electrochemical oxidation can be described using the pseudo-first-order kinetics model (Eq.5) [25]:

$$
\ln \frac{C_{t}}{C_{0}}=-k \cdot t
$$

where $t$ presents time in minutes, while $k\left(\mathrm{~min}^{-1}\right)$ is rate constant and $C_{t} / C_{0}$ are relative pesticide concentration. 
From an economic point of view, the energy consumption of direct electrochemical oxidation is very important to calculate the cost of the process. Energy consumption per volume of pesticide solution was estimated in $\mathrm{kWh} \mathrm{m}^{-3}$ and calculated by Eq.6 [25]:

$$
\text { Energy consumption }=\frac{U \cdot I \cdot t}{V}
$$

where $U$ is average cell voltage $(\mathrm{V}), I$ is average applied current (A), $t$ is electrolysis time expressed in hours and $V$ is the volume of the reactor $\left(\mathrm{m}^{3}\right)$.

\section{Results and Discussion}

\section{Effect of initial pesticide concentration}

The effect of initial concentration is important for reactor designing and calculation of the time required for treatment in a wastewater treatment plant. This effect was examined using the different initial concentration: $0.125,0.250,0.375$ and 0.5 $\mathrm{x} 10^{-4} \mathrm{M}$ of pesticide. Fig. 2 shows the influence of different TMX concentrations on the degradation rate and rate constants during direct electrochemical oxidation on $\mathrm{IrO}_{\mathrm{x}}$ anode.

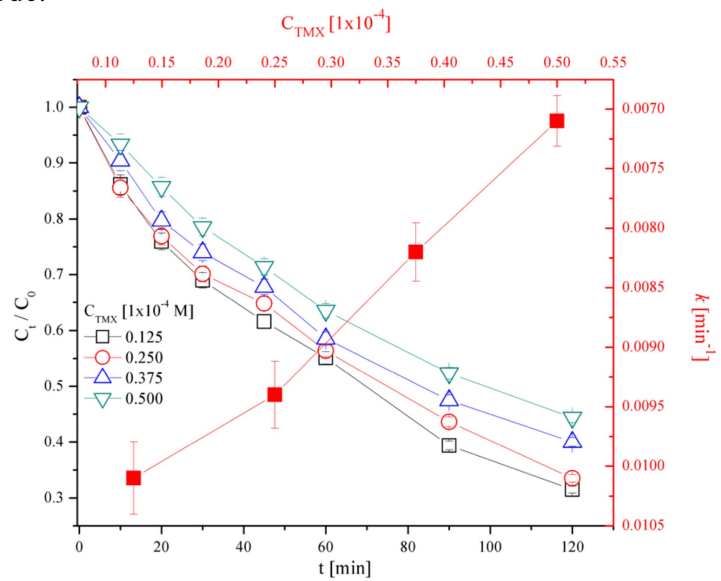

Figure 2. Dependence of direct electrochemical degradation of different relative thiamethoxam concentration (marked in the Figure) as a function of electrolysis time (black scale) and the dependence of reaction rate from thiamethoxam concentration (red scale). Conditions: $\left[\mathrm{Na}_{2} \mathrm{SO}_{4}\right]=0.25 \mathrm{M}$, $I=300 \mathrm{~mA}, \mathrm{pH}=5.8$.

As it can be seen from Fig.2, the neonicotinoid insecticide degradation efficiency was decreased with increase of the initial pesticide concentration after 120 minutes of the reaction time of direct electrochemical oxidation. Increase of the initial pesticide concentration initiated decrease of the degradation rate of thiamethoxam, for $68.5,66.5,60.0,55.6 \%$, respectively. The reaction rate dependence of thiamethoxam concentration is depicted in Fig.2 (red scale) and the pseudofirst order kinetics plot and rate constants for degradation of thiamethoxam at different initial pesticide concentration is presented in Fig.3. The rate constants were decreased from $0.0101 \mathrm{~min}^{-1}$ for $[\mathrm{TMX}]=0.125 \times 10^{-4} \mathrm{M}$ to $0.0071 \mathrm{~min}^{-1}$ for $[\mathrm{TMX}]=0.5 \times 10^{-4} \mathrm{M}$. The determined dependence is the result of insufficient adsorption site on the anode material at higher pesticide concentrations. The same phenomena were obtained by $\mathrm{Yao} \mathrm{Y}$. et al [26] using the $\mathrm{Yb}$-doped $\mathrm{PbO}_{2}$ anode for degradation neonicotinoid insecticide acetamiprid in presence of the $\mathrm{Na}_{2} \mathrm{SO}_{4}$ as an electrolyte, where degradation rate of acetamiprid after 120 minutes for a system with an initial concentration of $10 \mathrm{mg} \mathrm{L}^{-1}$ was $98.53 \%$ and for a system with $80 \mathrm{mg} \mathrm{L}^{-1}$ was $52.78 \%$.

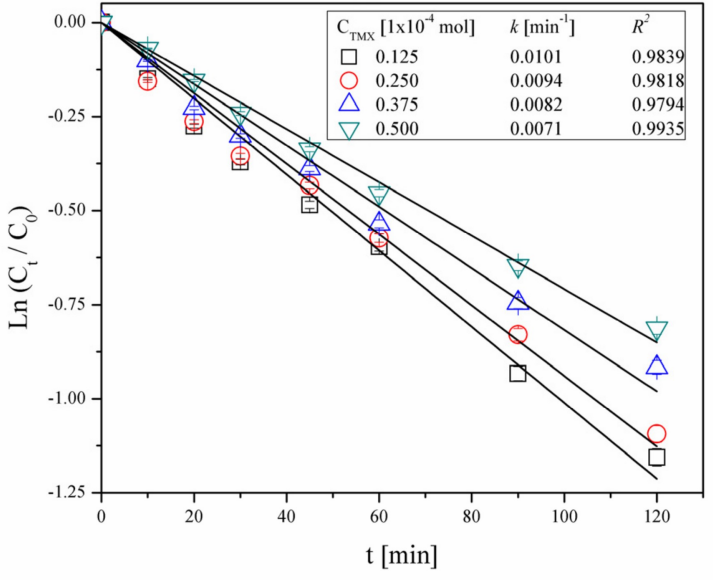

Figure 3. The pseudo-first order kinetics plot and rate constants for degradation of thiamethoxam at different initial pesticide concentration. Conditions: $\left[\mathrm{Na}_{2} \mathrm{SO}_{4}\right]=0.25 \mathrm{M}, I=300 \mathrm{~mA}, \mathrm{pH}=5.8$.

\section{Effect of electrolyte concentration}

During direct electrochemical oxidation, the presence of $\mathrm{Na}_{2} \mathrm{SO}_{4}$ as an electrolyte in a solution initiates an increase of solution conductivity and improves electron-transfer during degradation especially during oxygen evolution $[5,25,27,28]$. Effect of the electrolyte concentration was investigated at four different concentrations of $\mathrm{Na}_{2} \mathrm{SO}_{4}$ from 0.15 to $0.30 \mathrm{M}$. Results of the initial electrolyte concentrations and their pseudo-first order are presented in Fig.4. The pseudo-first order kinetics plot and rate constants for pesticide degradation at different initial electrolyte concentrations are depicted in Fig.5.

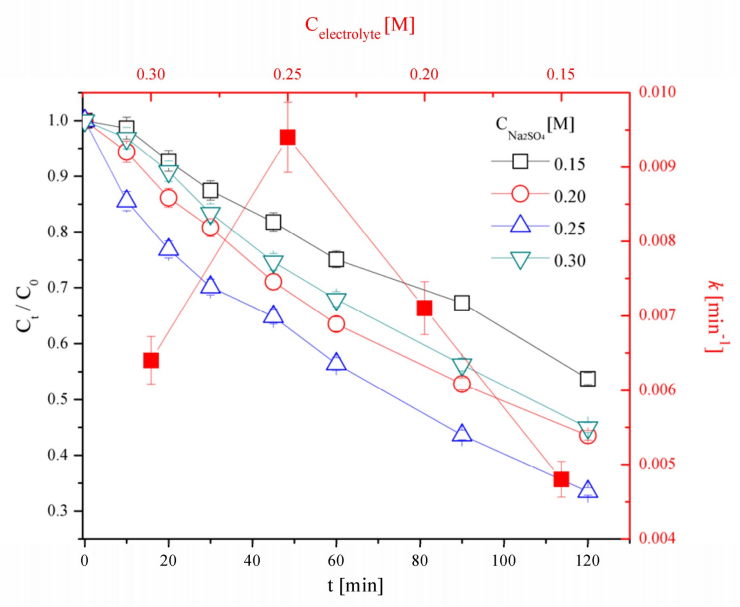

Figure 4. Dependence of direct electrochemical degradation of thiamethoxam of different electrolyte concentrations (marked in the Figure) as a function of electrolysis time (black scale) and the dependence of reaction rate from initial electrolyte (red scale) Conditions: $[\mathrm{TMX}]=0.25 \times 10^{-4} \mathrm{M}, I=300 \mathrm{~mA}, \mathrm{pH}=5.8$

Analyzing the results presented in Figures 4 and 5, it can be concluded that the increase of the electrolyte concentration to $0.25 \mathrm{M} \mathrm{Na}_{2} \mathrm{SO}_{4}$ initiate increase of process efficacy $(66.5 \%)$ and reaction rate $\left(k=0.0094 \mathrm{~min}^{-1}\right)$ as a result of forming higher concentrations of adsorbed radicals (Eq.1) and higher oxygen evolution (Eq.3). Further increase of electrolyte concentration decrease the efficacy of the process to $55 \%$ of degraded pesticide and reaction rate to $k=0.0065 \mathrm{~min}^{-1}$. Decreasing of the reaction rate can be caused by "scavenging" of formed hydroxyl radicals by $\mathrm{SO}_{4}{ }^{2-}$ ions (Eq.7) [29]: 
$\mathrm{SO}_{4}^{2^{-}}+\cdot \mathrm{OH} \rightarrow \mathrm{SO}_{4}^{--}+\mathrm{OH}^{-}$

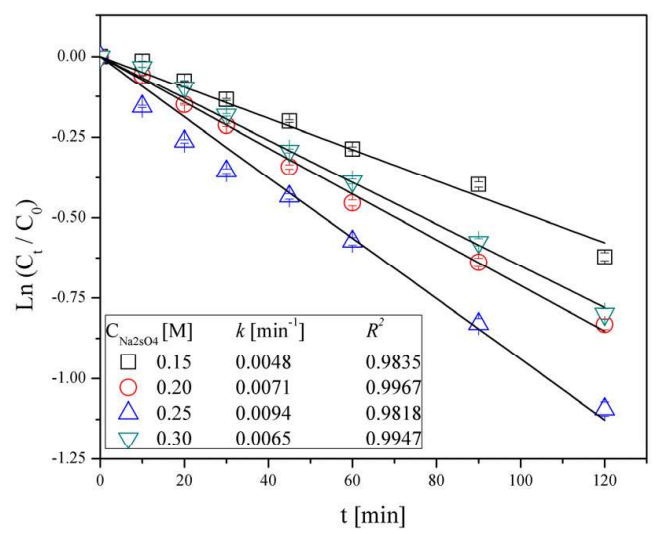

Figure 5. The pseudo-first order kinetics plot and rate constants for pesticide degradation at different initial electrolyte concentrations. Conditions: $[\mathrm{TMX}]=0.25 \times 10^{-4} \mathrm{M}, I=300 \mathrm{~mA}, \mathrm{pH}=5.8$.

The same phenomena were obtained during direct electrochemical oxidation of anthraquinone dye AB111, where the highest efficacy is obtained in the system with 0.17 $\mathrm{M}$ of $\mathrm{Na}_{2} \mathrm{SO}_{4}$ and further increasing of salt concentration initiates the decreasing the process efficacy [25]. LebikElhadi et al. [11] studied the degradation of thiamethoxam by direct electrochemical oxidation using a boron doped diamond anode at different initial conditions and shows high pesticide mineralization efficiency. By cited study, under the applied conditions $\left([\mathrm{TMX}]=2 \mathrm{mg} \mathrm{L}^{-1},\left[\mathrm{Na}_{2} \mathrm{SO}_{4}\right]=0.1 \mathrm{M}, I=16 \mathrm{~mA}\right.$ $\mathrm{cm}^{-2}$ ) thiamethoxam was completely degraded after 30 minutes.

\section{Effect of applied current}

In addition, direct electrochemical oxidation is highly dependent on the applied current [30]. The efficiency of thiamethoxam degradation by direct electrochemical oxidation using $\mathrm{IrO}_{\mathrm{x}}$ anode was tested using five values of the applied current in the range 100-300 mA. Fig. 6 presents the results of insecticide degradation (black scale) and the dependence of reaction rate from applied current during the reaction (red scale) at different values at the applied current during electrolysis time. The pseudo-first order kinetics plot and rate constants for pesticide degradation at different applied current are depicted in Fig.7.

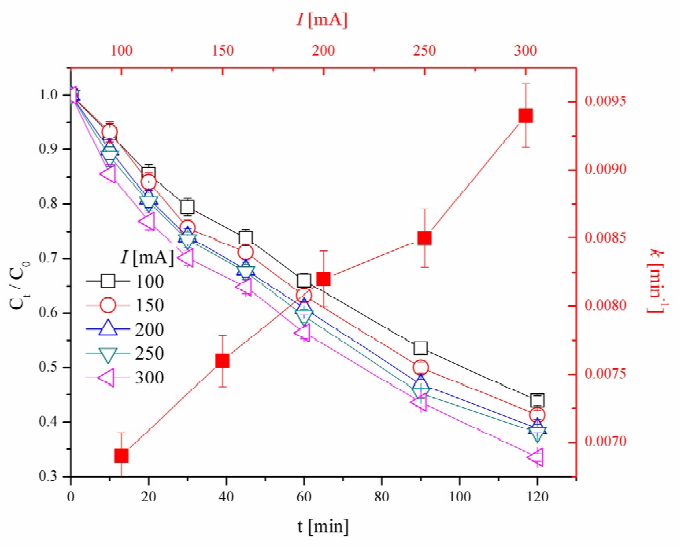

Figure 6. Dependence of direct electrochemical degradation of thiamethoxam of different applied current (marked in the figure) as a function of electrolysis time (black scale) and the dependence of reaction rate from applied current (red scale). Conditions: $[\mathrm{TMX}]=0.25 \times 10^{-4} \mathrm{M},\left[\mathrm{Na}_{2} \mathrm{SO}_{4}\right]=0.25 \mathrm{M}, \mathrm{pH}=5.8$.

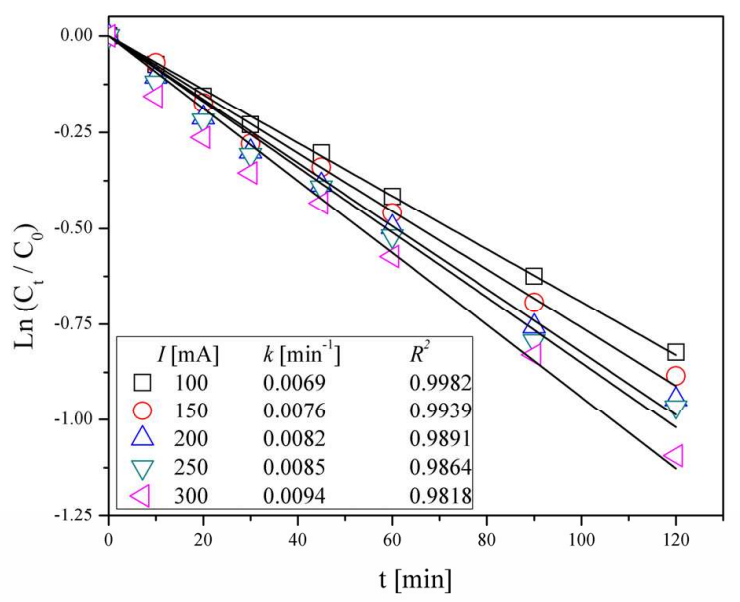

Figure 7. The pseudo-first order kinetics plot and rate constants for pesticide degradation at different applied current. Conditions: $[\mathrm{TMX}]=0.25 \times 10^{-4} \mathrm{M}$, $\left[\mathrm{Na}_{2} \mathrm{SO}_{4}\right]=0.25 \mathrm{M}, \mathrm{pH}=5.8$.

Presented results show the influence of reaction rate: at the lowest applied current, the concentration of thiamethoxam decreased by $57.1 \%$ and the reaction rate was $k=0.0069 \mathrm{~min}^{-1}$ while increase of the applied current value increases the reaction rate. At the highest value of applied current $(I=300$ $\mathrm{mA}), 66.5 \%$ of the initial pesticide amount was degraded and the reaction rate was $k=0.0094 \mathrm{~min}^{-1}$. The same correlation between increase of the applied current and increase of the reaction rate was obtained in our previous paper [25]. Increase of the applied current caused an increase of the formation of adsorbed radicals (Eq.1) and led to the forming of higher oxides (Eq.2), or oxygen evolution reaction (Eq.3).

\section{Effect of initial $\mathrm{pH}$ value}

The effect of the initial solution $\mathrm{pH}$ value was examined at acidic ( $\mathrm{pH} 3.0)$, at $\mathrm{pH}$ value without adjustment ( $\mathrm{pH}$ 5.8) and at alkali (pH 11.0) conditions. The results of the influence of the $\mathrm{pH}$ values at the beginning of insecticide degradation and the dependence of the reaction rate from initial $\mathrm{pH}$ value during the process are presented in Fig. 8. The pseudo-first order kinetics plot and rate constants for pesticide degradation at different initial electrolyte concentrations are depicted in Fig.9.

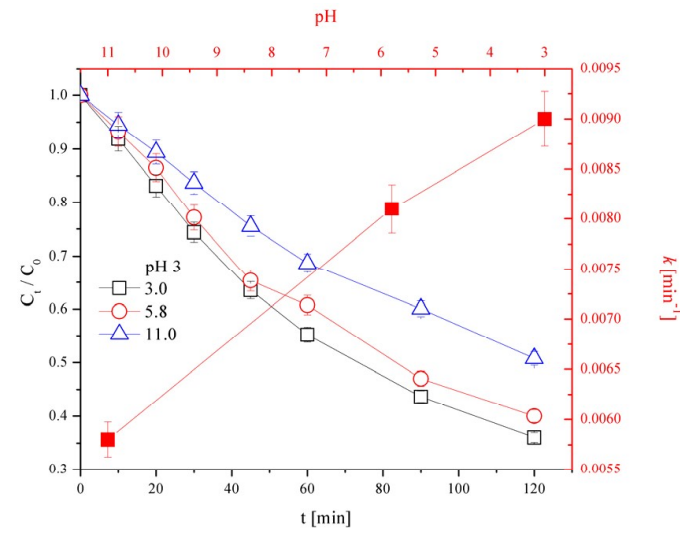

Figure 8. Dependence of direct electrochemical degradation of thiamethoxam of different initial $\mathrm{pH}$ value (marked in the figure) as a function of electrolysis time (black scale) and the dependence of reaction rate from initial $\mathrm{pH}$ value (red scale). Conditions: $[\mathrm{TMX}]=0.25 \times 10^{-4} \mathrm{M},\left[\mathrm{Na}_{2} \mathrm{SO}_{4}\right]=0.25 \mathrm{M}$.

Analyzing the presented results, the reaction rate depends on the initial $\mathrm{pH}$ value of the solution, at the acidic aqueous medium ( $\mathrm{pH} 3.0$ ) reaction rate was $k=0.0090 \mathrm{~min}^{-1}$, and increase of the $\mathrm{pH}$ value to 11.0 initiate decrease of the 
reaction rate $\left(k=0.0058 \mathrm{~min}^{-1}\right)$. The degradation rate has the same trend, the increase of process efficacy follows the decrease of $\mathrm{pH}$ value. In an acidic solution, $66.5 \%$ of thiamethoxam is degraded, and in alkali solution ( $\mathrm{pH} 11)$ was degraded $49.3 \%$ of thiamethoxam. The same trend was obtained in thiamethoxam degrading by electrochemical oxidation using the BDD electrode [11]. Possible explanations for this trend are higher hydroxyl radicals production on the surface of the electrode at a lower $\mathrm{pH}$ value [31] while in alkaline solution the generation of $\mathrm{OH}^{-}$is increased which causes a decrease of the reaction rate [25].

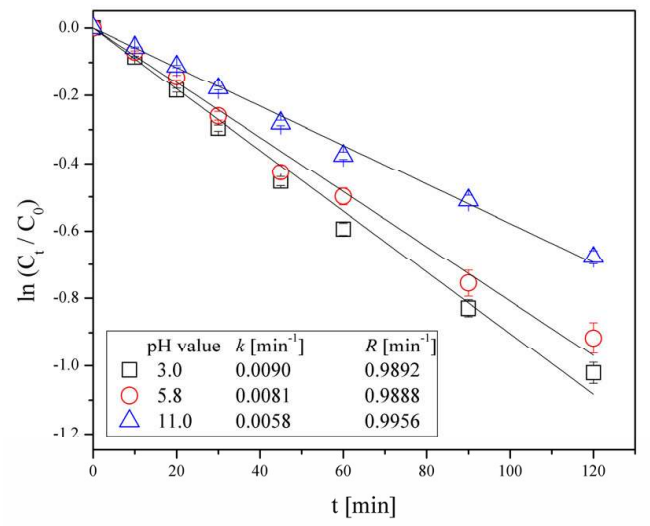

Figure 9. The pseudo-first order kinetics plot and rate constants for pesticide degradation at different initial $\mathrm{pH}$ value. Conditions: $[\mathrm{TMX}]=0.25 \times 10^{-4} \mathrm{M}$, $\left[\mathrm{Na}_{2} \mathrm{SO}_{4}\right]=0.25 \mathrm{M}$.

\section{Energy consumption}

From the aspect of cost-effectiveness of the direct electrochemical oxidation of insecticide thiamethoxam, the most important factor is energy consumption. Energy consumption was calculated using Eq.6. Fig.10 presents the dependence of the relative voltage of the applied current.

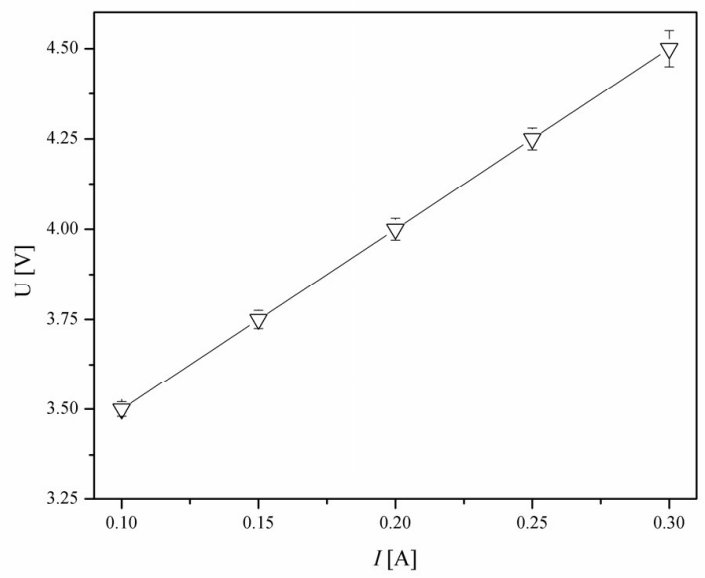

Figure 10. The relative voltage versus applied current in the direct electrochemical oxidation of thiamethoxam. Conditions: $[\mathrm{TMX}]=0.25 \times 10^{-4}$ $\mathrm{M},\left[\mathrm{Na}_{2} \mathrm{SO}_{4}\right]=0.25 \mathrm{M}, \mathrm{pH}=5.8$.

Analyzing the result obtained by Eq. 6 and from Fig.10, for the lowest applied current, the voltage was $3.5 \mathrm{~V}$ and the calculated energy consumption was $3.5 \mathrm{kWh} \mathrm{m}^{-3}$. Increase of the used applied current causes increase of the voltage to $4.5 \mathrm{~V}$ and energy consumption to $13.5 \mathrm{kWh} \mathrm{m}^{-3}$. Using the highest applied current increases the reaction rate from $k=0.0069 \mathrm{~min}^{-1}$ to $k=0.0094$ $\mathrm{min}^{-1}$ which causes an increase of the energy consumption and has a negative effect on the cost-effectiveness of the process.

\section{UV-Vis spectra}

Parameters obtained by following the decrease of the thiamethoxam absorption peak at $251 \mathrm{~nm}$ of UV-Vis spectra during electrolysis time was used for kinetic parameters calculations. The UV-Vis spectra change during thiamethoxam degradation reaction under optimal conditions is presented in Fig.11.

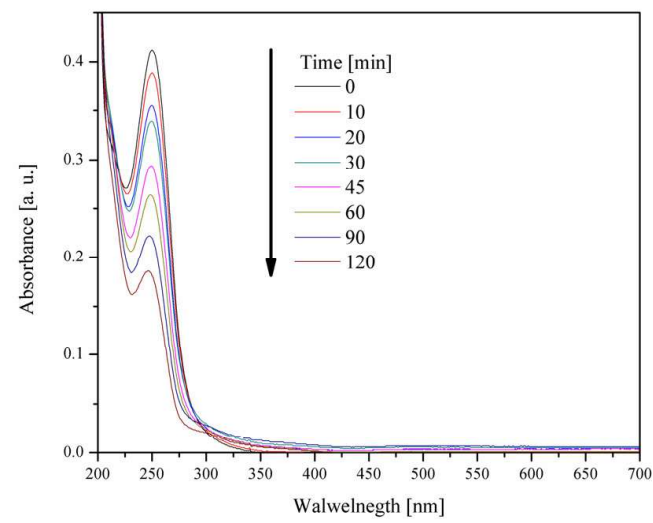

Figure 11. Typical UV/Vis spectra of thiamethoxam during direct electrochemical oxidation process. Conditions: $[\mathrm{TMX}]=0.25 \times 10^{-4} \mathrm{M}$, $\left[\mathrm{Na}_{2} \mathrm{SO}_{4}\right]=0.25 \mathrm{M}, I=300 \mathrm{~mA}, \mathrm{pH}=5.8$.

The maximum absorption peak of thiamethoxam is at 251 $\mathrm{nm}$ (Fig.7). A change in the thiamethoxam absorption peak is observed during electrolysis time and decrease of absorbance value after 120 minutes shows the efficiency of the process over time. After 120 minutes, according to the measured absorbance value at $251 \mathrm{~nm}$, the pesticide concentration was decreased to $60.0 \%$.

\section{Conclusion}

Direct electrochemical oxidation of thiamethoxam can be well described using the pseudo-first-order kinetic model. The increase of the initial pesticide concentration decreases the process efficacy and the reaction rate. The optimal $\mathrm{Na}_{2} \mathrm{SO}_{4}$ concentration is $0.25 \mathrm{M}$, while the higher concentrations initiates "scavenging" of hydroxyl radicals by sulphate ions. The direct electrochemical degradation in acidic solution is more efficient.

Increase of the applied current causes acceleration of redox reactions on the electrode surface, thus the process efficacy is higher at $300 \mathrm{~mA}$ than in the system with $100 \mathrm{~mA}$. On the other side, use of higher applied current makes the process more expensive.

So, the optimal conditions for direct electrochemical oxidation of thiamethoxam are $[\mathrm{TMX}]=0.25 \times 10^{-4} \mathrm{M}$, $\left[\mathrm{Na}_{2} \mathrm{SO}_{4}\right]=0.25 \mathrm{M}, \mathrm{pH}=5.8$.

\section{Acknowlengement}

The research covered in this paper was carried out in the framework of the University of Defense, Project No. VATT/1/18-20.

\section{Reference}

[1] RALOFF,J.: Agent Orange and Birth Defects Risk, Science News, 1984, Vol. 126, No. 8, p. 117.

[2] TUCKER,C.S.: The Encyclopedia of the Vietnam War: a Political, Social and Military History 2nd ed. - Defoliation, ABC-CLIO, 2011.

[3] TOKUDA,Y., KIKUCHI,M., TAKAHASHI,O.: Prehospital Management of Sarin Nerve Gas Terrorism in Urban Settings: 10 Years of Progress After the Tokyo Subway Sarin Attack, Resuscitation, 2006, Vol. 68, No. 2, pp. 193-202.

[4] CALDERBANK,A.: Chapter 6: Organophosphorus Insecticides. In Peacock, F.C. (ed.). Jealott's Hill: Fifty years of Agricultural Research 1928-1978. Imperial Chemical Industries Ltd., 1978. 
[5] TARIQUE,M., KUMAR,M., MALIK,A.: Mutagenicity, genotoxicity and oxidative stress induced by pesticide industry wastewater using bacterial and plant bioassays, Biotechnology Reports, 2019, Vol. 24, pp. e00389.

[6] SILONARDO,J., VIEIRA,L., CARVALHO,W., BENVINDOSOUZA,M.: Mutagenic, genotoxic and morphotoxic potential of different pesticides in the erythrocytes of Podocnemis expansa neonates, Science of the Total Environment, 2020, Vol.737, p. 140304.

[7] ANJUM,R., MALIK,A.: Evaluation of mutagenicity of wastewater in the vicinity of pesticide industry, Environmental Toxicology and Pharmacology, 2013, Vol. 35, No.2, pp.284-291.

[8] WANG,Z., BROOKS,B.W., ZENG,E.Y., YOU,J.: Comparative mammalian hazards of neonicotinoid insecticides among exposure durations, Environment International, 2019, Vol.125, pp.9-24.

[9] WANG,T., AI,S., ZHOU,Y, LUO,Z., DAI,C., YANG,Y., ZHANG,J., HUANG,H., LUO,S., LUO,L.: Adsorption of agricultural wastewater contaminated with antibiotics, pesticides and toxic metals by functionalized magnetic nanoparticles, Journal of Environmental Chemical Engineering, 2018, Vol. 6, No.5, pp.6468-6478.

[10] BADAWY,M.I., GHALY,M.Y., GAD-ALLAH,T.A.: Advanced oxidation processes for the removal of organo- phosphorus pesticides from wastewater, Desalination, 2006, Vol.194, pp.166-175.

[11] LEBIK-ELHADI,H., FRONTISTIS,Z., AIT-AMAR,H., AMRANI,S., MANTZAVINOS,D.: Electrochemical oxidation of pesticide thiamethoxam on boron doped diamond anode: Role of operating parameters and matrix effect, Process Safety and Environmental Protection, 2018, Vol.116, pp.535-541.

[12] BADELLINO, C., RODRIGUES, C.A., BERTAZZOLI, R.: Oxidation of pesticides by in situ electrogenerated hydrogen peroxide: Study for the degradation of 2,4-dichlorophenoxyacetic acid, Journal of Hazardous Material, 2006, Vol.137, No.2, pp.856-864.

[13] LU,L.A., MAB,Y.S., KUMAR,M., LIN,J.G.: Photo-fenton pretreatment of carbofuran -analyses via experimental design, detoxification and biodegradability enhancement, Separation and Purification Technology, 2011, Vol.81, No.3, pp.325-331.

[14] SALEH,I.A., ZOUARI,N., AL-GHOUTI,M.A.: Removal of pesticides from water and wastewater: Chemical, physical and biological treatment approaches, Environmental Technology \& Innovation, 2020, Vol.19, p.101026.

[15] AKSU,Z.: Application of biosorption for the removal of organic pollutants. A review, Process Biochemistry, 2005, Vol.40, pp.997-1026.

[16] WANG,Y., WANG,S., XIE,T., CAO,J.: Activated carbon derived from waste tangerine seed for the high-performance adsorption of carbamate pesticides from water and plant, Bioresource Technology, 2020, Vol.316, p.123929.

[17] LI,C., XIE,Y., GUO,Y., CHENG,Y., YU,H., QIAN,H., YAO,W.: Effects of ozone-microbubble treatment on the removal of residual pesticides and the adsorption mechanism of pesticides onto the apple matrix, Food Control, 2020, Vol. 120, p. 107548.

[18] HACHAMI,F., ERRAMI,M., BAZZI,L., HILALI,M., SALGHI,R., JODEH,S., HAMMOUTI,B., HAMED,O.: A comparative study of electrochemical oxidation of methidation organophosphorous pesticide on $\mathrm{SnO} 2$ and boron-doped diamond anodes, Chemistry Central Journal, 2015, Vol. 9, No. 59, pp. 1-7.

[19] MALAKOOTIAN,M., SHAHESMAEILI,A., FARAJI,M., AMIRI,H.: Advanced oxidation processes for the removal of organophosphorus pesticides in aqueous matrices: A systematic review and meta-analysis, Process Safety and Environmental Protection, 2020, Vol.134, pp.292-307.

[20] AWAD,H.S., GALWA,N.A.: Electrochemical degradation of Acid
Blue and Basic Brown dyes on Pb/PbO2 electrode in the presence of different conductive electrolyte and effect of various operating factors, Chemosphere, 2005, Vol. 61, No. 9, pp. 1327-1335.

[21] ZHANG,F., FENG,C., LI,W., CUI,J.: Indirect Electrochemical Oxidation of Dye Wastewater Containing Acid Orange 7 Using Ti/ $\mathrm{RuO} 2$-Pt Electrode, International Journal of Electrochemical Science, 2014, Vol. 9, pp. 943-954.

[22] BASS,C., DENHOLM,I., WILLIAMSON,M.S., NAUEN,R.: The global status of insect resistance to neonicotinoid insecticides, Pesticide Biochemistry and Physiology, 2015, Vol. 121, pp. 78-87.

[23] WANG,A., MAHAI,G., WAN,Y., JIANG,Y., MENG,Q., XIA,W., HE,Z., XU,S.: Neonicotinoids and carbendazim in indoor dust from three cities in China : Spatial and temporal variations, Science of the Total Environment, 2019, Vol. 695, p. 133790.

[24] WANG,H., TANG,C., YANG,J., WANG,N., JIANG,F., XIA,Q Predictors of urinary antibiotics in children of Shanghai and health risk assessment, Environment International, 2018, Vol. 121, pp. 507-514.

[25] STUPAR, S.LJ., GRGUR, B.N., ONJIA, A.E., MIJIN, D.: Direct and indirect electrochemical degradation of acid blue 111 using IrOX anode, International Journal of Electrochemical Science, 2017, Vol. 12, No. 9, pp. 8564-8577.

[26] YAO,Y., TENG,G., YANG,Y., HUANG,C., LIU,B., GUO,L.: Electrochemical oxidation of acetamiprid using Yb-doped $\mathrm{PbO} 2$ electrodes: Electrode characterization, influencing factors and degradation pathways, Separation and Purification Technology, 2018, Vol. 211, pp. 456-466.

[27] MARTÍNEZ-HUITLE,C.A., FERRO,S.: Electrochemical oxidation of organic pollutants for the wastewater treatment: direct and indirect processes, Chemical Society Reviews, 2006, Vol.35, No.12, pp.1324-1340.

[28] GUZMAN-DUQUE,F.L., PALMA-GOYES,R.E., GONZALEZ,I., PENUELA,G., TORRES-PALMA,R.A.: Relationship between anode material, supporting electrolyte and current density during electrochemical degradation of organic compounds in water, Journal of Hazardous Materials, 2014, Vol.278, pp.221-226.

[29] DUGANDŽIĆ,A.M., TOMAŠEVIĆ,A.V., $\quad$ RADIŠIĆ,M.M., ŠEKULJICA,N., MIJIN,D., PETROVIĆ,S.D.: Effect of inorganic ions, photosensitisers and scavengers on the photocatalytic degradation of nicosulfuron, Journal of Photochemistry and Photobiology A: Chemistry, 2017, Vol.336, pp.146-155.

[30] HE,S., HUANG,Q., ZHANG,Y., WANG,L., NIE, Y.: Investigation on Direct and Indirect Electrochemical Oxidation of Ammonia over Ru$\mathrm{Ir} / \mathrm{TiO}{ }_{2}$ Anode, Industrial \& Engineering Chemistry Research, 2015, Vol.54, No.5, pp.1447-1451.

[31] ADRIAN,T., CHIORCEA-PAQUIM,A., FATIBELLO-FILHO,O., OLIVEIRA-BRETT,A.M.: Electrochemistry Communications Hydroxyl radicals electrochemically generated in situ on a borondoped diamond electrode, Electrochemistry Communications., 2009, Vol.11, No.7, pp.1342-1345.

[32] ZHANG,F., ZHANG,Y., H. NI,MA, K.LI, R.: Experimental and DFT studies on the vibrational, electronic spectra and NBO analysis of thiamethoxam, Spectrochimica Acta Part A: Molecular and Biomolecular Spectroscopy, Vol.118, pp.162-171, 2014.

[33] PERIASAMY,A., MURUGANAND,S., AND PALANISWAMY,M.: Vibrational studies of $\mathrm{Na}_{2} \mathrm{SO}_{4}, \mathrm{~K}_{2} \mathrm{SO}_{4}, \mathrm{NaHSO}_{4}$ and $\mathrm{KHSO}_{4}$ crystals, Rasayan Journal of Chemistry, 2009, Vol. 2, No.4, pp.981-989.

Received: 29.10 .2020 Accepted: 18.11.2020.

\title{
Istraživanje direktne elektrohemijske oksidacije neonikotinoidnog pesticida tiametoksam u vodi
}

\begin{abstract}
Poslednjih decenija očigledna je sve veća upotreba hemikalija na mnogo načina u savremenom životu. Stoga je mogućnost njegovog unosa u organizme, trovanja ljudi i životinja i oštećenja zdravlja, danas na visokom nivou, posebno kada su u pitanju katastrofe izazvane upotrebom toksičnih hemikalija u terorističkim napadima ili u vojne svrhe. Ako gledamo unapred, rizik od zagađenja vode i tla pesticidima, kao jednima od najvažnijih resursa za preživljavanje, uvek je prisutan. Široki spektri negativnih efekata pesticida na životnu sredinu iniciraju sve veći broj ispitivanja efikasnih metoda uklanjanja pesticida, posebno iz vode. Cilj ovog rada bio je da se ispita efikasnost direktne elektrohemijske oksidacije kao metoda za insitu razgradnju pesticida u vodenoj sredini, u zavisnosti od koncentracije pesticida, prisutnih elektrolita, primenjene struje i pH vrednosti medijuma. Kao model molekula korišćen je neonikotinoidni pesticid tiametoksam. Kinetika razgradnje tiametoksama u vodenom rastvoru praćena je UV/Vis spektrometrijom.
\end{abstract}

Ključne reči: elektrohemijska oksidacija, pesticidi, kinetički parametri, IrOX anoda, potrošnja energije, UV/Vis spektroskopija. 